\title{
Rekstur Landspítala - fjárframlög í samræmi við hlutverk
}

\section{Páll}

\section{Matthíasson}

Höfundur er geðlæknir og forstjóri Landspítala.

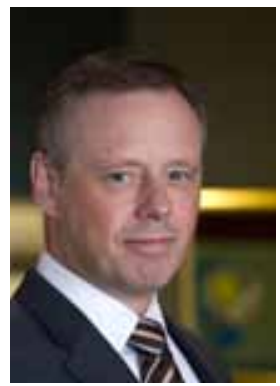

pallmatt@landspitali.is

Frá hruni (og líklega lengur) hefur fjórðungur hvers árs hjá stjórnendum Landspítala að verulegu leyti farið í að berjast fyrir fjárframlögum sem dugi til reksturs pjóðarsjúkrahússins. Ekki fé til að gera nýja og framsýna hluti, heldur í harða baráttu fyrir fjármunum til lögbundinna verkefna spítalans.

Landspítali hefur fengið gagnrýni á síðustu vikum vegna umframkeyrslu fjárlaga, samkvæmt 6 mánaða uppgjöri. Pó skeikar einungis um $2 \%$, sem skýrist af ófyrirsjáanlegum breytileika í heilbrigðispjónustu par sem sveiflur eru í eftirspurn og óhægt um vik að takmarka starfsemi. Á Landspítala er vel farið með fjármuni og peim varið til verkefna sem bæta öryggi og pjónustu við sjúklinga. Hvað veldur pví pá að spítalinn hefur á fyrri hluta pessa árs farið fram úr fjárlögum?

Fyrstu mánuðir pessa árs sýna starfsemisaukningu á legudeildum Landspítala miðað við 2013 sem birtist í hærri meðalfjölda inniliggjandi sjúklinga í hverjum mánuði miðað við árið á undan. Mismunurinn nær hámarki á sumarmánuðum og jafngildir allt að tveimur legudeildum. Aukningin er mest á kvennadeildum og vökudeild auk nokkurra legudeilda lyflækninga- og skurðlækningasviða. Rúmanýting spítalans er of há og ekkert má pví út af bera svo ekki komi til endurtekinnar „rúmakrísu“ með tilheyrandi gangayfirlögnum, álagi á starfsfólk, yfirvinnu og öryggisógn.

Annar kostnaðarsamur páttur - og öryggisógn - er vaxandi óhagræði af gömlu húsnæði sem dreift er út um allar porpagrundir, en einnig gífurlega kostnaðarsamt (og að mestu ófjármagnað) viðhald peirra húsa. •að mál mun fyrst leysast með nýbyggingum á Landspítalalóð. Par til úr rætist erum við tilneydd að stunda látlausa flutninga á veiku fólki, tækjum og verðmætu starfsfólki fram og aftur um bæinn.

Aðrir stórir pættir sem rétt er að nefna eru óleyst mál varðandi kostnað mjög dýrra líftæknilyfja. Pá má geta pess að ólíkir útreikningar fjármálaráðuneytis og Landspítala á áhrifum kjara- og stofnanasamninga leiða oft til pess að Landspítali fær launakostnað ekki bættan að fullu, sem er í raun ígildi sparnaðarkröfu. Einnig má nefna ógreiddar skuldir annarra sjúkrastofnana við spítalann. Samanlagt er parna um hærri fjárhæðir að ræða en nemur halla spítalans.

Ljóst er að fjárveitingar til Landspítala eru enn ekki nægar. Benda má á að hver framleiðslueining á Karolinska háskólasjúkrahúsinu kostar 58\% meira en á Landspítala. En rekstrarkostnaður Landspítala árið 2014 á föstu verðlagi, án tækjakaupa, er nærri 4,5 milljörðum króna lægri en árið 2008! Frá 2008 hefur orðið mikil frampróun í sérhæfðri sjúkrahúspjónustu, frampróun sem skilar sér í betri heilsu - en kostar fé. Jafnframt hefur pví heiðursfólki sem komið er á efri ár fjölgað. Раð kostar einnig, pví eldri sjúklingar eiga við fleiri og erfiðari vandamál að etja og purfa oft lengri tíma til að ná sér.

Afleiðingar langtíma fjársveltis eru ljósar. Í mörgum skilningi náði Landspítali botninum árið 2013. Par héldust í hendur ónóg fjármögnun til lengri tíma og sem afleiðing af pví minni starfsánægja en áður hafði mælst. Hallinn nam tæplega 1500 milljónum króna og mikil ólga varð meðal starfsfólks. Рað tekur tíma að snúa peirri próun við. Stjórnvöld settu inn nauðsynlegt viðbótarfjármagn árið 2014 sem hefur gert okkur kleift að fá viðspyrnu. Leiðin sem hefur verið farin til pess að hefja viðspyrnu spítalans árið 2014 var í fyrsta lagi að bæta eftir mætti tæki og húsnæði, í öðru lagi að bæta starfsskilyrði starfsfólks og í priðja lagi að bregðast við flóknum rekstrarvanda með ýmsum hætti og nýttist um pað bil helmingur viðbótarfjármagns í rekstur.

Fyrst og fremst purfum við pó uppbyggingu húsnæðis Landspítala og sameiningu bráđapjónustu á Hringbraut. Endurnýjun húsnæðis er ekki óparfi, heldur lykilpáttur í pví að tryggja öryggi og pjónustu heilbrigðispjónustunnar. Par vitum við að Alpingi stendur á bak við okkur ${ }^{1}$ og við treystum pví að hægt verði að finna leiðir til að fjármagna uppbygginguna sem allra allra fyrst, pví engan tíma má missa.

Við starfsfólk Landspítala stöndum að sjálfsögðu áfram vörð um pann hornstein heilbrigðispjónustunnar sem pjóðarsjúkrahúsið er. Við treystum pví að stjórnvöld sýni pví skilning að minniháttar sveiflur í rekstri jafnstórrar pjónustustofnunar eru eðlilegar og ekki merki um óráðsíu. Við purfum líka skilning á pví að enn vantar sem nemur nokkrum prósentum í rekstrargrunn Landspítala, eigi hann að geta sinnt peim verkefnum sem honum eru falin. Alpingi hefur vissulega mikilvægu hlutverki að gegna sem eftirlitsaðili með pví almannafé sem pað deilir út til stofnana. Раð er hins vegar sameiginlegt verkefni okkar að tryggja landsmönnum pá heilbrigðispjónustu sem peir hafa rétt til. Með fullnægjandi fjárveitingum í takt við raunverulegan kostnað við pá pjónustu sem Landspítala er ætlað að sinna, má komast hjá endurteknum deilum um keisarans skegg.

1althingi.is/altext/143/s/1249.html

Running the National University Hospital - budgeting must meet service requirements

Páll Matthíasson, MD MRCPsych PhD, is a consultant psychiatrist, a clinical Associate Professor at The University of Iceland and the CEO of Landspitali - The National University Hospital of Iceland. 